\title{
UJI AKTIVITAS ANTINYAMUK LOTION MINYAK KUNYIT SEBAGAI ALTERNATIF PENCEGAH PENYEBARAN DEMAM BERDARAH DENGUE
}

\author{
Lidya Ameliana, Lina Winarti \\ Bagian Farmasetika, Fakultas Farmasi, Universitas Jember, Jember, Jawa Timur \\ e-mail : lidyaameliana@yahoo.co.id
}

\begin{abstract}
This research aims to create a lotion formula containing essential oils of turmeric (Curcuma longa) as well as find out its activities as Aedes aegypti repellent. Turmeric rhizome steam distilled essential oil fraction to be taken. Lotion is made by mixing turmeric oil with a base with a concentration of $10 \%, 15 \%$, and $20 \%$. Preparation activity tested against Aedes aegypti mosquito that is by calculating the protection time. As a negative control use basis only, whereas the positive control used the patent lotion. From the test results obtained activity results lotion protection time in a row were $1.33 \pm 0.34,3.33 \pm 0.38,11.43 \pm 1.50$, and 21.67 \pm 2.08 minutes. Preparations that have their greatest protection is lotion which contains turmeric oils of 20\%. In addition to the activity test also tests the physical properties of turmeric oil lotion, i.e organoleptic test, $\mathrm{pH}$, spreadibility test, and viscosity. All tests of physical properties were fullfilled the criteria lotion preparations. Then the $p H$ and spreadibility tested again after being stored for 1 month. $p H$ of lotion not experience significant differences compared to when newly created, while the spreadibility changed after being stored 1 month.
\end{abstract}

Keywords: lotion, turmeric oil, repellent, Aedes aegypti

\begin{abstract}
ABSTRAK
Penelitian ini bertujuan untuk membuat formula sediaan lotion yang mengandung minyak atsiri kunyit (Curcuma longa) sekaligus mengetahui aktivitasnya sebagai antinyamuk Aedes aegypti. Rimpang kunyit didestilasi uap untuk diambil minyak atsirinya. Lotion dibuat dengan mencampurkan minyak kunyit dengan basis dengan konsentrasi $10 \%, 15 \%$, dan $20 \%$. Aktivitas sediaan diuji terhadap nyamuk Aedes aegypti yaitu dengan menghitung waktu perlindungannya. Sebagai kontrol negatif digunakan basis saja. Dari hasil uji aktivitas didapatkan hasil waktu perlindungan lotion berturut-turut adalah $1,33 \pm 0,34 ; 3,33 \pm 0,38$; $11,43 \pm 1,50$; dan $21,67 \pm 2,08$ menit. Sediaan yang memiliki waktu perlindungan terbesar adalah lotion yang mengandung minyak atsiri $20 \%$. Selain dilakukan uji aktivitas juga dilakukan uji sifat fisik lotion minyak kunyit, yaitu uji organoleptis, $\mathrm{pH}$, daya sebar, dan viskositas. Semua uji sifat fisik memenuhi kriteria sediaan lotion. Kemudian $\mathrm{pH}$ dan daya sebar dan lotion diuji lagi setelah disimpan selama 1 bulan. $\mathrm{pH}$ lotion tidak mengalami perbedaan bermakna dibandingkan dengan ketika baru dibuat, sedangkan daya sebarnya mengalami perubahan setelah disimpan 1 bulan.
\end{abstract}

Kata kunci: lotion, minyak kunyit, repelan, Aedes aegypti 


\section{PENDAHULUAN}

Nyamuk merupakan salah satu serangga penghisap darah (antropofilik) yang sering menimbulkan gangguan pada manusia. Indonesia dengan iklim tropisnya merupakan tempat yang baik bagi perkembang biakan nyamuk. Nyamuk mengganggu bukan hanya gigitannya yang menimbulkan rasa nyeri, dan mungkin reaksi alergi, tetapi beberapa nyamuk berperan sebagai vektor penyakit parasitik seperti malaria, demam berdarah, chikungunya, filariasis, enchepalitis dan lain-lain [1,2].

Nyamuk Culex, Aedes dan Anopheles merupakan nyamuk yang perlu mendapat perhatian serius karena merupakan vektor bagi penyakit. Culex dikenal sebagai vektor japanese encephalitis, Anopheles sebagai vektor penyakit malaria sedangkan Aedes dikenal sebagai vektor penyakit demam berdarah dengue, chikungunya, dan yellow Fever [3].

Demam berdarah termasuk penyakit yang cukup meresahkan masyarakat karena penyebarannya sangat cepat dan tidak jarang menyebabkan kematian. Diperkirakan sudah banyak korban terenggut akibat penyakit ini [4]. Salah satu cara yang dapat ditempuh untuk mengatasinya adalah dengan memutus rantai penularan dengan mengendalikan vektor penyakit tersebut $[5,6]$.

Pengendalian vektor tersebut dapat dilakukan dengan cara menghindari gigitan nyamuk dengan menggunakan kelambu waktu tidur, mengoles kulit dengan repelan gosok, membunuh larva nyamuk, membunuh nyamuk dewasa, menghilangkan atau mengurangi tempat perindukannya [7].
Tindakan preventif paling dini yang dapat dilakukan oleh setiap individu dalam pengendalian vektor adalah dengan melakukan proteksi diri terhadap gigitan nyamuk Aedes aegypti dengan menggunakan repelan. Repelan yang banyak beredar di masyarakat sebagian besar mengandung bahan kimia, yaitu DEET (N, N-diethyl- $m$-tolumide) $12,5 \%$. Efek yang ditimbulkan dari penggunaan DEET yang patut dicurigai adalah aphasia, anemia aplastik, ataxia, karsinogenesis, gagal jantung, kejang depresi, disorientasi, dorsofleksi ibu jari, iritasi mata, mata berdarah, konjungtivitis, luka pada kornea, hipertrofi hepar, ginjal, limpa, dan testis, jaundice, mutagenenesis, prenatal damage, kegagalan pernafasan, kekakuan pada posisi duduk, gemetar [8]. Oleh karena itu, untuk membatasi penggunaan DEET sebagai repelan maka perlu dicari repelan alternatif yang aman, nyaman dan efektif untuk mencegah gigitan nyamuk. Salah satu cara adalah dengan memanfaatkan bahan dari alam. Salah satunya dengan menggunakan bahan alam yaitu kunyit.

Kunyit di masyarakat dikenal sebagai bahan bumbu masakan. Selain itu juga dikenal sebagai bahan obat alamiah yang sering digunakan dalam campuran jamu tradisional. Tawatsin et al. [9] telah menguji bahwa minyak atsiri dari rimpang kunyit (Curcuma domestica), dengan konsentrasi $25 \% \mathrm{v} / \mathrm{v}$ dalam etanol absolut tanpa adisi vanilin 5\%, memiliki efikasi yang baik dalam menolak nyamuk Aedes aegypti selama 1 jam, dan nyamuk Anopheles dirus selama 8 jam. Dengan adisi vanilin 5\%, minyak atsiri kunyit dapat menolak nyamuk dalam waktu yang lebih lama, yaitu nyamuk Aedes aegypti selama 4,5 jam dan nyamuk Anopheles dirus selama minimal 8 jam. Dari hasil penelitian tersebut diharapkan dapat dikembangkan sebuah sediaan alternatif repelan yang menggunakan bahan alami yaitu kunyit. 
Bentuk sediaan yang dipilih pada penelitian ini adalah lotion. Lotion memungkinkan pemakaian yang merata dan cepat pada permukaan kulit yang luas. Lotion segera kering pada kulit setelah pemakaian dan meninggalkan lapisan tipis dari komponen obat pada permukaan kulit [10].

Tujuan dari penelitian ini adalah membuat sediaan lotion minyak kunyit (Curcuma domestica) dan mengetahui waktu perlindungannya dari nyamuk Aedes aegypti sebagai vektor virus Demam Berdarah Dengue.

\section{METODE}

Penelitian ini dilakukan di laboratorium Biologi Farmasi, laboratorium Farmasetika Fakultas Farmasi Universitas Jember dan Tropical Disease Centre UNAIR Surabaya.

Bahan-bahan yang digunakan untuk penelitian ini : kunyit, PEG 4000, Stearil alkohol, Na Lauril Sulfat, etanol $96 \%$, gliserin, nipagin, aquades, nyamuk Aedes aegypti betina, tangan naracoba.

Alat-alat yang digunakan : seperangkat alat destilasi, Refraktometer ABBE, penangas air, pot salep, Viscometer Rion VT-04, pHmeter, neraca, sangkar nyamuk, mortir dan stamper, dan alat-alat gelas.

Isolasi minyak kunyit dilakukan dengan penyulingan menggunakan air. Pada proses penyulingan terjadi kontak langsung antara rimpang kunyit dengan air. Simplisia yang telah dipotong-potong, kemudian sebanyak $100 \mathrm{~g}$ dimasukkan ke dalam labu destilasi, ditambah aquades secukupnya dan dididihkan. Selanjutnya labu destilasi dipasang.

Labu dipanaskan dengan penangas udara sehingga penyulingan terjadi dengan lambat tapi teratur. Minyak atsiri yang terbawa bersama uap air dialirkan melalui pendingin. Minyak yang belum murni akan mengembun dan ditampung dalam vial melalui adaptor. Gambar alat destilasi minyak kunyit dapat dilihat pada gambar 1 . Formula basis gel seperti pada tabel 1 .

\begin{tabular}{cc}
\multicolumn{2}{c}{ Tabel 1. Formula Basis Lotion } \\
\hline Bahan & Jumlah (gram) \\
\hline PEG 4000 & 15 \\
Stearil alkohol & 10 \\
Gliserin & 10 \\
Na Lauril sulfat & 1 \\
Nipagin & 0,3 \\
Aquades ad & 300 \\
\hline
\end{tabular}

Dibuat empat macam formula minyak atsiri kunyit dengan konsentrasi $0 \%, 10 \%$, $15 \%$ dan $20 \%$ b/v. Pembuatan basis dilakukan dengan cara ditimbang minyak kunyit : $0 \mathrm{~g}, 1 \mathrm{~g}, 1,5 \mathrm{~g}$ dan $2 \mathrm{~g}$ masingmasing dicampur dengan basis lotion sampai homogen dan tiap-tiap formula mempunyai berat 10 gram.

Uji sifat fisis lotion kunyit meliputi uji daya sebar, viskositas, dan $\mathrm{pH}$ lotion. Uji daya sebar dilakukan dengan cara: lotion ditimbang seberat 0,5 gram, diletakkan di tengah lempeng kaca bulat berskala dengan diameter kaca $15 \mathrm{~cm}$. Di atas lotion diletakkan kaca bulat lain dan pemberat sehingga berat kaca bulat dan pemberat 150 gram, didiamkan selama 1 menit, kemudian dicatat penyebarannya.

Pengukuran viskositas meng-gunakan alat Viscometer Rion (RION-JAPAN) yang sesuai (seri VT-03E atau VT-04E). Kecepatan pada alat tersebut $62,5 \mathrm{rpm}$. Caranya lotion dimasukkan dalam wadah dan dipasang pada portable viscotester. Viskositas lotion diketahui dengan mengamati gerakan jarum penunjuk viskositas. Penentuan $\mathrm{pH}$ lotion dilakukan menggunakan $\mathrm{pH}$ Meter dengan prosedur sebagai berikut: lotion sebanyak $1 \mathrm{~g}$ 
diletakkan dalam Erlenmeyer kemudian diencerkan dengan sejumlah tertentu air dan diaduk hingga tercampur. Kemudian pH Meter dicelupkan kedalam lotion yang telah diencerkan dan dilihat nilai $\mathrm{pH}$ yang tertera pada $\mathrm{pH}$ Meter. Penentuan $\mathrm{pH}$ dilakukan dengan replikasi sebanyak tiga kali untuk masing-masing formula. Uji aktivitas repelan dilakukan secara eksperimental. Hewan uji dikelompokkan menjadi dua yaitu kelompok kontrol dan kelompok bahan uji. Sangkar yang digunakan berukuran 20x20×20 dengan lubang sirkuler berdiameter $15 \mathrm{~cm}$, disiapkan sebanyak 2 buah sangkar yang berisi 30 ekor nyamuk Aedes aegypti yang belum pernah digigitkan, dipuasakan sehari sebelum percobaan. Tangan peneliti dibersihkan dengan air dan diberi tanda berukuran 3 x $10 \mathrm{~cm}$, diolesi lotion sebanyak $75 \mathrm{mg}$ [11] didiamkan selama 2-3 menit, dimasukkan ke dalam sangkar nyamuk. Pada kelompok kontrol negatif diberi perlakuan dengan memasukkan tangan naracoba yang telah dioleskan basis. Waktu penolakan ditetapkan untuk menentukan lamanya tangan naracoba didiamkan dalam sangkar uji pada saat pengujian efek masing-masing repelan. Kontrol negatif menunjukkan bahwa pada pengujian senyawa uji tidak ada intervensi dari bahan pembawa. Pada kelompok bahan uji, tangan naracoba dibersihkan dengan air dan diolesi dengan lotion dibiarkan selama 30 menit, kemudian dimasukkan ke dalam sangkar nyamuk 5 menit, catat jumlah gigitan nyamuk dan nyamuk yang menempel pada tangan. Waktu pertama kali nyamuk Aedes aegypti menggigit setelah tangan naracoba diolesi dengan repelan disebut waktu penolakan. Bentuk alat uji aktivitas antinyamuk dapat dilihat pada gambar 2 .

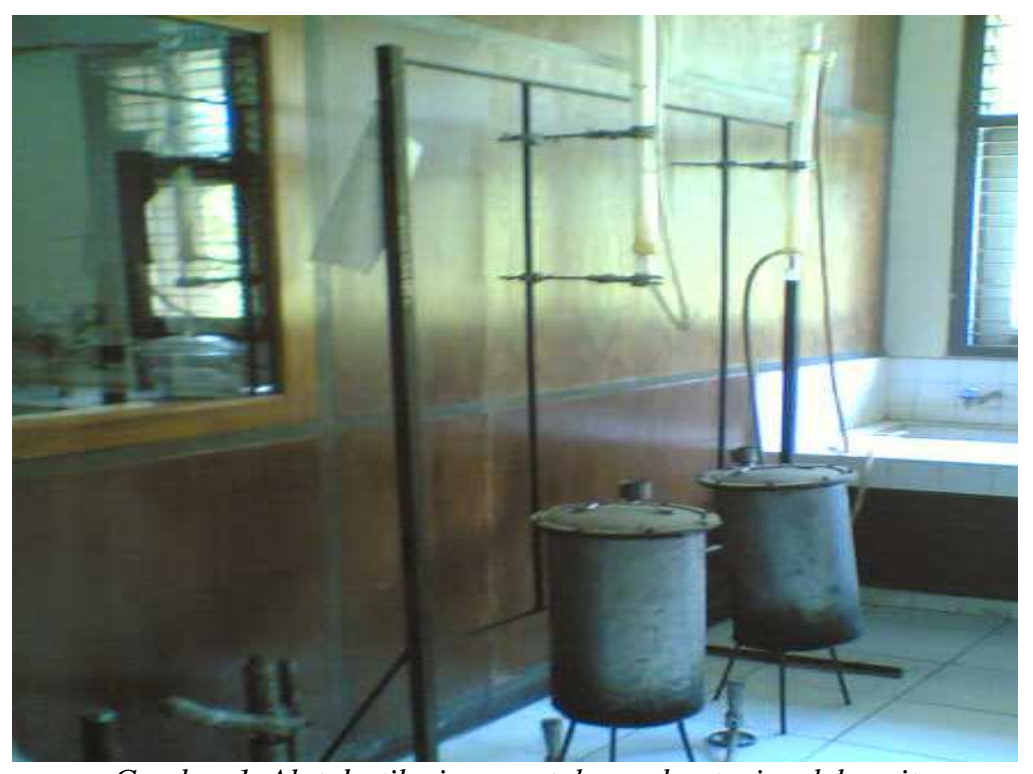

Gambar 1. Alat destilasi uap untuk membuat minyak kunyit 


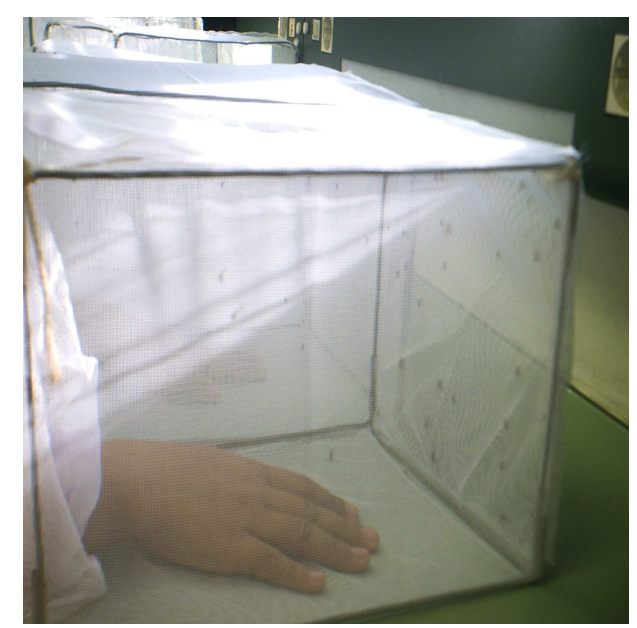

Gambar 2. Alat uji aktivitas antinyamuk

Tabel 2. Hasil Uji Organoleptis Lotion Minyak Kunyit

\begin{tabular}{cccc}
\hline Konsentrasi $(\%)$ & Warna & Bau & Memisah/tidak \\
\hline 0 & Bening & Tak berbau & Tidak \\
10 & Putih kekuningan & Agak aromatik & Tidak \\
15 & Putih keruh kekuningan & Aromatik & Tidak \\
20 & Kuning-putih-keruh & Sangat aromatik & Tidak \\
\hline
\end{tabular}

\section{HASIL DAN PEMBAHASAN}

Tanaman kunyit yang digunakan pada penelitian ini diperoleh dari Pasar Tanjung Kabupaten Jember. Berdasarkan identifikasi oleh Herbarium Jemberiense, ditetapkan bahwa kunyit yang digunakan merupakan spesies Curcuma domestica (Curcuma longa).

Isolasi minyak kunyit dilakukan dengan metode destilasi uap air menggunakan simplisia sebanyak $100 \mathrm{~kg}$. Minyak kunyit yang diperoleh sebanyak $132,5 \mathrm{ml}$ dengan rendemen $0,1325 \%$. Selanjutnya minyak kunyit diuji indeks bias, hasilnya adalah 1,517 .

Selanjutnya dibuat formula lotion sesuai dengan rancangan formula yaitu lotion yang mengandung minyak kunyit $0 \%, 10$ $\%, 15 \%$, dan $20 \%$. Hasil uji organoleptis lotion minyak kunyit dapat diamati pada tabel 2.
Semakin tinggi konsentrasi minyak kunyit dalam basis lotion maka semakin aromatik baunya yaitu memilki bau khas seperti kunyit. Konsentrasi minyak kunyit juga mempengaruhi warna lotion yang dihasilkan. Basis lotion berwarna putih keruh dan semakin tinggi konsentrasi minyak kunyit dalam basis semakin kuning intensitas warna lotion.

Lotion minyak kunyit yang diperoleh menunjukan bahwa basis lotion dapat mendukung minyak kunyit karena minyak atsiri dan basis dapat membentuk lotion. Tidak terlihat adanya pemisahan antara basis dan minyak pada semua konsentrasi. Hal tersebut dapat diamati berdasarkan hasil uji organoleptis. Tidak terjadinya pemisahan minyak terhadap basis dikarenakan adanya emulgator $\mathrm{Na}$ Lauril sulfat pada lotion. Emulgator dapat membantu mendispersikan minyak ke dalam basis dalam bentuk misel sehingga tidak mengalami pemisahan 
Uji $\mathrm{pH}$ dilakukan untuk mengetahui besarnya $\mathrm{pH}$ pada masing-masing konsentrasi serta pengaruh penambahan minyak kunyit terhadap $\mathrm{pH}$ sediaan. Hasil pengujian $\mathrm{pH}$ lotion dengan berbagai konsentrasi minyak kunyit ditunjukkan dalam tabel 3.

Hasil uji statistik pH lotion didapatkan bahwa nilai $\mathrm{p}=0,001$, karena nilai $\mathrm{p}<0,05$ maka berarti terdapat perbedaan bermakna nilai $\mathrm{pH}$ antara ketiga formula. Semakin tinggi konsentrasi minyak kunyit dalam basis lotion maka semakin kecil $\mathrm{pH}$ sediaan. Hal ini karena $\mathrm{pH}$ minyak kunyit asam (pH 4).

Menurut Anief [12] $\mathrm{pH}$ kulit mendekati netral yaitu berkisar antara 4,5-6,5 sedangkan dari hasil uji $\mathrm{pH}$ didapatkan bahwa $\mathrm{pH}$ lotion pada berbagai konsentrasi rata-rata 6,57-7,40 seperti ditunjukkan pada tabel 3 diatas. Kesesuaian nilai $\mathrm{pH}$ sediaan topikal dengan $\mathrm{pH}$ kulit mempengaruhi penerimaan kulit terhadap sediaan. Sediaan topikal yang ideal adalah tidak mengiritasi kulit [12]. Kemungkinan iritasi kulit akan sangat besar apabila sediaan terlalu asam atau terlalu basa karena repelan topikal membutuhkan kontak yang lama dengan kulit. Sehingga dari nilai $\mathrm{pH}$ tersebut dapat dinyatakan bahwa lotion minyak kunyit pada berbagai konsentrasi relatif aman untuk pemakaian topikal.

Daya sebar adalah kemampuan penyebaran sediaan topikal pada kulit.. Uji daya sebar dilakukan untuk mengetahui besarnya penyebaran lotion saat dioleskan pada kulit. Lotion yang baik harus mempunyai daya sebar yang cukup sehingga memudahkan pengaplikasian pada kulit. Hasil pengujian daya sebar lotion dengan berbagai konsentrasi minyak kunyit ditunjukkan dalam tabel 4 .

Tabel 3. Hasil Uji pH Lotion Minyak Kunyit

\begin{tabular}{ccccc}
\hline \multirow{2}{*}{$\begin{array}{c}\text { Konsentrasi } \\
(\%)\end{array}$} & \multicolumn{4}{c}{$\mathrm{pH}$} \\
\cline { 2 - 5 } & 1 & 2 & 3 & Replikasi \\
\hline 10 & 7,3 & 7,4 & 7,5 & $7,40 \pm 0,10$ \\
15 & 7,1 & 6,8 & 6,8 & $6,90 \pm 0,17$ \\
20 & 6,5 & 6,7 & 6,5 & $6,57 \pm 0,12$ \\
\hline
\end{tabular}

Tabel 4. Hasil Uji Daya Sebar Lotion Minyak Kunyit

\begin{tabular}{ccccc}
\hline \multirow{2}{*}{$\begin{array}{c}\text { Konsentrasi } \\
(\%)\end{array}$} & \multicolumn{4}{c}{ Daya Sebar $(\mathrm{cm})$} \\
\cline { 2 - 5 } & 1 & 2 & 3 & Replikasi \\
\cline { 2 - 5 } & 5,4 & 5,6 & 5,7 & $5,57 \pm 0,15$ \\
10 & 4,8 & 5,8 & 6,0 & $5,53 \pm 0,64$ \\
20 & 6,8 & 6,5 & 6,5 & $6,60 \pm 0,17$ \\
\hline
\end{tabular}

Tabel 5. Hasil Uji Viskositas Lotion Minyak Kunyit

\begin{tabular}{cc}
\hline Konsentrasi (\%) & Viskositas (dPas) \\
\hline 10 & 42 \\
15 & 36 \\
20 & 33 \\
\hline
\end{tabular}


Untuk sediaan lotion, didapatkan nilai $\mathrm{p}=0,026$, karena nilai $\mathrm{p}<0,05$ maka berarti ada perbedaan bermakna daya sebar lotion antar konsentrasi. Semakin tinggi konsentrasi minyak kunyit maka semakin besar kemampuan daya sebar lotion, karena konsistensi minyak kunyit yang cair menyebabkan semakin tinggi konsentrasi minyak kunyit semakin besar daya sebar lotion. Lotion yang paling baik penyebarannya adalah pada konsentrasi $20 \%$ sebab semakin besar nilai penyebaran sediaan maka semakin mudah sediaan tersebut untuk dioleskan [12].

Viskositas adalah suatu parameter yang menyatakan tahanan yang mencegah zat untuk mengalir. Makin tinggi viskositasnya maka semakin tinggi pula tahanannya [13]. Hasil pengujian viskositas lotion dengan berbagai konsentrasi minyak kunyit ditunjukkan dalam tabel 5.

Berdasarkan hasil uji viskositas lotion didapatkan bahwa semakin tinggi konsentrasi minyak kunyit yang ditambahkan viskositasnya semakin rendah, karena konsistensi minyak kunyit yang lebih cair dibandingkan basis sediaan sehingga menyebabkan viskositasnya semakin rendah dengan penambahan konsentrasi minyak kunyit.

Setelah uji sifat fisika kimia dilanjutkan dengan uji aktivitas repelan lotion minyak kunyit terhadap Aedes aegypti L. Repelan merupakan bahan kimia atau non-kimia yang dioleskan pada kulit dan berkhasiat mencegah nyamuk hinggap [6]. Uji aktivitas repelan menggunakan 30 ekor nyamuk betina berumur 3 hari yang telah dipuasakan sehari sebelumnya dan tidak pernah menghisap darah. Aktivitas repelan dinyatakan dengan waktu perlindungan (protection time) dalam satuan menit. Hasil uji aktivitas repelan ditunjukkan dalam tabel 6 .
Dari hasil uji statistik aktivitas lotion, didapat harga $\mathrm{p}=0,000$, karena $\mathrm{p}<0,05$ maka berarti terdapat perbedaan bermakna waktu perlindungan sediaan antar formula. Semakin tinggi konsentrasi minyak kunyit semakin tinggi waktu perlindungannya.

Selanjutnya sediaan disimpan dalam waktu 1 bulan dan diamati lagi $\mathrm{pH}$ dan daya sebarnya untuk mengetahui apakah terjadi perubahan $\mathrm{pH}$ dan daya sebar lotion selama penyimpanan 1 bulan. Hasil pengamatan pH lotion dapat dilihat pada tabel 7 .

Dari hasil uji statistik dengan derajat kepercayaan $95 \%$ didapatkan harga $\mathrm{p}=$ 0,244 . Karena nilai $p>0,05$ maka berarti tidak ada perbedaan bermakna nilai $\mathrm{pH}$ lotion yang baru dibuat dengan nilai $\mathrm{pH}$ setelah penyimpanan selama 1 bulan. Namun uji $\mathrm{pH}$ ini perlu dilakukan lagi untuk jangka waktu yang lebih panjang untuk mengetahui stabilitas $\mathrm{pH}$ lotion selama penyimpanan.

Selain uji $\mathrm{pH}$, dilakukan juga uji daya sebar pada sediaan yang sudah disimpan selama 1 bulan. Hasil uji daya sebar lotion setelah penyimpanan selama 1 bulan dapat dilihat pada tabel 8 .

Dari hasil uji statistik dengan derajat kepercayaan $95 \%$, didapatkan harga $\mathrm{p}=0,01$. Karena nilai $\mathrm{p}<0,05$ maka berarti terdapat perbedaan bermakna nilai daya sebar sediaan yang baru dibuat dengan setelah disimpan selama 1 bulan. Perbedaan nilai daya sebar disini menunjukkan adanya perubahan konsistensi lotion yaitu penurunan daya sebar sediaan. Hal ini disebabkan terjadinya penguapan air yang terkandung dalam lotion selama penyimpanan, sehingga konsistensi sediaan menjadi lebih kental dan terjadi penurunan daya sebar sediaan. 
Uji Aktivitas Antinyamuk Lotion Minyak Kunyit Sebagai Alternatif Pencegah Penyebaran Demam Berdarah Dengue

Tabel 6. Hasil Uji Aktivitas Lotion Minyak Kunyit

\begin{tabular}{|c|c|c|c|c|}
\hline \multirow{3}{*}{$\begin{array}{c}\text { Konsentrasi } \\
(\%)\end{array}$} & \multicolumn{4}{|c|}{ Waktu Perlindungan (menit) } \\
\hline & \multicolumn{4}{|c|}{ Replikasi } \\
\hline & 1 & 2 & 3 & Rata-rata \pm SD \\
\hline 0 (basis) & 1,00 & 1,33 & 1,67 & $1,33 \pm 0,34$ \\
\hline 10 & 3,00 & 3,25 & 3,75 & $3,33 \pm 0,38$ \\
\hline 15 & 10,00 & 11,33 & 13,00 & $11,43 \pm 1,50$ \\
\hline 20 & 20,00 & 21,00 & 24,00 & $21,67 \pm 2,08$ \\
\hline
\end{tabular}

Tabel 7. Hasil Uji pH Lotion Minyak Kunyit selama Penyimpanan 1 Bulan

\begin{tabular}{ccccc}
\hline \multirow{2}{*}{$\begin{array}{c}\text { Konsentrasi } \\
(\%)\end{array}$} & \multicolumn{4}{c}{$\mathrm{pH}$} \\
\cline { 2 - 5 } & 1 & 2 & 3 & Replikasi \\
\cline { 2 - 5 } & 7,5 & 7,8 & 7,7 & $7,67 \pm 0,15$ \\
10 & 7,8 & 7,6 & 7,6 & $7,67 \pm 0,12$ \\
15 & 7,5 & 7,5 & 7,6 & $7,53 \pm 0,06$ \\
\hline
\end{tabular}

Tabel 8. Hasil Uji Daya Sebar Lotion Minyak Kunyit selama Penyimpanan 1 Bulan

\begin{tabular}{ccccc}
\hline \multirow{2}{*}{$\begin{array}{c}\text { Konsentrasi } \\
(\%)\end{array}$} & \multicolumn{4}{c}{ Daya Sebar $(\mathrm{cm})$} \\
\cline { 2 - 5 } & 1 & 2 & 3 & Replikasi \\
\hline 10 & 3.8 & 4,4 & 4,0 & $4,07 \pm 0,31$ \\
15 & 4,4 & 4,8 & 4,5 & $4,57 \pm 0,21$ \\
20 & 4,2 & 4,4 & 4,6 & $4.34 \pm 0,30$ \\
\hline
\end{tabular}

\section{KESIMPULAN}

Kesimpulan penelitian ini adalah minyak kunyit dapat diformulasi menjadi sediaan lotion anti-nyamuk dan memiliki sifat fisik ( $\mathrm{pH}$, daya sebar, dan viskositas) yang memenuhi persyaratan lotion. Lotion dengan konsentrasi $0 \%, 10 \%, 15 \%$, dan $20 \%$ memiliki waktu perlindungan berturut-turut adalah $1,33 \pm 0,34 ; 3,33 \pm$ 0,$38 ; 11,43 \pm 1,50 ;$ dan $21,67 \pm 2,08$ menit. Formula yang memiliki waktu perlindungan terlama adalah lotion dengan konsentrasi minyak atsiri 20\%. Pada penyimpanan sediaan lotion selama 1 bulan, lotion tidak mengalami perubahan $\mathrm{pH}$ tetapi mengalami perubahan daya sebar sediaan.

Saran untuk penelitian ini adalah perlu dikembangkan formula sediaan topikal dari minyak kunyit yang memiliki aktivitas yang sama atau lebih besar dari sediaan lotion antinyamuk DEET yang sudah ada di pasaran. Selain itu juga perlu dilakukan uji stabilitas sediaan lotion untuk memenuhi kualitas sediaan tersebut.

\section{UCAPAN TERIMA KASIH}

Disampaikan terima kasih kepada Nur Hayati Mufarrihah yang telah membantu penelitian dan kepada DIKTI (DP2M tahun 2008) sebagai sumber dana penelitian ini.

\section{DAFTAR PUSTAKA}

1. Eldridge, B. 1999, Mosquitoes, Integrated Pest Management Around The Home, Pest Notes, University of California Division of Agriculture and Natural Resources.

2. Herms, B.W. 1950, Medical Entomology, 4th, The Mc. Millan Co; New York

3. Rachmat, M. 1984, Epidemiologi DBD di Sulawesi Selatan, Simposium Demam Berdarah Dengue, Ikatan Dokter Indonesia; Ujung Pandang 
4. Karinan, A. 2001, Pestisida Nabati Ramuan dan Aplikasi, P.T. Penebar Swadaya; Jakarta

5. Fradin, M.S.; \& J.F. Day.; 2002. Comparative Efficacy of Insect Repellents Against Mosquito Bites, New England J. Medicine, 347:13-8.

6. Hoedojo. 1983, Vektor Demam Berdarah Dengue dan Upaya Penanggulangannya, Majalah Parasitologi Indonesia.

7. Kurniawati, dkk. 2006, Uji efektivitas filtrat sereh (Andropogon nardus) sebagai insektisida nabati dalam upaya memberantas nyamuk Aedes aegypti, Kumpulan makalah PIMNAS $X I X$, Universitas Muha-madiyah Malang.

8. Cunningham.; \& Hallenback. 1985, Pesticides and Human Health, Springer-Verla; New York.
9. Tawatsin, A.; Wratten, S. D.; Scott, R.R.; Thavara, U.; \& Techadamrongsin, Y. 2001, Repellency of volatile oils from plants against three mosquito vectors, J. Vector Ecology 26 (1): 76-82.

10. Ansel, H.C. 1985, Pengantar Sediaan Farmasi, Jakarta : UI Press.

11. Environmental Protection Agency (EPA). 1999, Insect Repellents for Human Skin and Outdoor Premises, US EPA.

12. Anief, M. 2000, Farmasetika, Gadjah Mada University Press; Yogyakarta, Halaman 30.

13. Voight, R. 1995, Buku Pelajaran Teknologi Farmasi, Gadjah Mada University Press; Yogyakarta 